九州大学学術情報リポジトリ

Kyushu University Institutional Repository

\title{
Effect of Selected Food Additives on Biofilm Formation by Foodborne Pathogens on Stainless Steel
}

\section{SHEN, Cunkuan}

Department of Bioscience and Biotechnology, Graduate School of Bioscience and Bioenvironmental Sciences, Kyushu University

MACHIDA, Chikako

Department of Bioscience and Biotechnology, Graduate School of Bioscience and Bioenvironmental Sciences, Kyushu University

MASUDA, Yoshimitsu

Department of Bioscience and Biotechnology, Faculty of Agriculture, Graduate School, Kyushu University

HONJOH, Ken-ichi

Department of Bioscience and Biotechnology, Faculty of Agriculture, Graduate School, Kyushu University

他

https://doi.org/10.5109/4363550

出版情報：九州大学大学院農学研究院紀要. 66 (1)，pp.45-52，2021-03-01. Faculty of Agriculture， Kyushu University

バージョン :

権利関係 : 


\title{
Effect of Selected Food Additives on Biofilm Formation by Foodborne Pathogens on Stainless Steel
}

\author{
Cunkuan SHEN ${ }^{1}$, Chikako MACHIDA ${ }^{1}$, Yoshimitsu MASUDA ${ }^{2}$, \\ Ken-ichi HONJOH ${ }^{2}$ and Takahisa MIYAMOTO ${ }^{2 *}$
}

\author{
Laboratory of Food Hygienic Chemistry, Division of Food Science and Biotechnology, \\ Department of Bioscience and Biotechnology, Faculty of Agriculture, \\ Kyushu University, Fukuoka 819-0395, Japan \\ (Received October 6, 2020 and accepted November 4, 2020)
}

\begin{abstract}
The effects of food additives, including sucrose fatty acid ester with C18 (SFE C18) and monoglycerin fatty acid ester with C18 (MFE C18), gardenia yellow pigment (GY), monascus pigment (MP), milk serum protein (MSP), protamine (PT) and polylysine (PL) on biofilm formation by pathogenic and spoilage bacteria on stainless-steel were investigated. Salmonella Enteritidis, S. Typhimurium, Pseudomonas aeruginosa, P. fluorescens, Listeria monocytogenes and Staphylococcus aureus were cultivated with food additives at different concentrations, followed by evaluation of biofilm formation and viable counts after 24 or 48 h. SFE C18 inhibited biofilm formation by $S$. Enteritidis, S. Typhimurium and L. monocytogenes at $0.005 \%(w / w)$. The inhibition of biofilm formation by MFE C18 was weaker than that of SFE C18. GY reduced more than $50 \%$ of biofilm formation by $S$. Typhimurium even at $0.01 \%$. MP greatly decreased biofilm formation of $S$. Enteritidis at $0.1 \%$. MSP inhibited biofilm formation of $S$. Enteritidis and $S$. aureus at $0.0025 \%$, but not those of $S$. Typhimurium, P. aeruginosa and L. monocytogenes at $0.025 \%$. PT greatly reduced the biofilm formation of $S$. Enteritidis, $S$. Typhimurium and $S$. aureus with increasing PT concentration from 0.001 to $0.1 \%$. PL inhibited biofilm formation on stainless steel by $S$. Enteritidis, $S$. Typhimurium, and L. monocytogenes with increasing PL concentration from 0.001 to $0.1 \%$. In contrast, Biofilm formation of $P$. aeruginosa was promoted by GY, PT, and PL, that of $S$. aureus by MP, and P. fluorescens by PT at the concentrations effectively decreased those of the other bacteria. Especially, $0.1 \%$ PT and $0.01 \%$ PL killed planktonic cells of $P$. aeruginosa though increased the biofilm formation of the bacterium.
\end{abstract}

Key words: biofilm, food additives, foodborne-pathogens, stainless steel

\section{INTRODUCTION}

Biofilms are sessile and complex communities where bacterial cells are embedded in a matrix of extracellular polymeric substance (EPS) produced by the microorganisms. Compared with their planktonic counterparts, bacteria in the biofilms are far more difficult to eradicate because of the enhanced resistance to antimicrobials. Various pathogenic bacteria such as Salmonella, Listeria, Pseudomonas and Staphylococcus have been linked to foodborne disease outbreaks from consumption of dairy products, chicken, fruits and packaged salads. According a report regarding global foodborne burden published by the WHO, pathogenic bacteria accounted for over 50 percentage of the approximately 600 million cases of foodborne illness globally in 2010 (World Health Organization, 2015). Therefore, biofilm formation by food-borne pathogens during food processing is always a great concern especially in fresh produce safety, as biofilms on food processing equipment and contact surfaces can be continuous sources of contamination and lead to cross-contamination of bacteria in the food processing environments (Beuchat, 2002).

\footnotetext{
1 Department of Bioscience and Biotechnology, Graduate School of Bioscience and Bioenvironmental Sciences, Kyushu University

2 Department of Bioscience and Biotechnology, Faculty of Agriculture, Graduate School, Kyushu University

* Corresponding author (E-mail: tmiyamot@agr.kyushu-u.ac.jp)
}

Because of abundant nutrients and water in food processing lines, pathogenic and spoilage bacteria are more prone to form biofilms on surfaces of utensils and equipment, it is of particular importance for food manufacturing industry to depend on regular cleaning and disinfection procedure for the purpose of ensuring food safety and quality. However, biofilms located in the inaccessible areas of some food processing equipment can easily evade cleaning treatments (Diaz et al., 2016). In addition, commonly used chemical disinfectant, such as sodium hypochlorite and its derivatives are not preferred especially during fresh-cut industry owing to the increasing concerns of their toxicity and safety issues (Meireles et al., 2016).

Thus, developing alternative disinfectants has always been a hot spot in the area of reducing prevalence of foodborne pathogens in food industry. Previously, we have reported that several selected food additives, such as Sucrose fatty acids ester (SFE) with fatty acid of C8 to C18, Monoglycerin fatty ester (MFE) with fatty acid of C8 to C18, Gardenia yellow pigment (GY), Monascus pigment (MP), Protamine (PT), $\varepsilon$-Polylysine (PL), and Milk serum protein (MSP) were effective to inhibit the initial attachment of several common pathogenic bacteria onto plastic surfaces of microtiter plate (Miyamoto et al., 2011; Islam et al., 2014). Also, the inhibition effect can be enhanced by combination of some selected food additives on microtiter plate and proved to be useful in reducing secondary-contami- 
nated Salmonella on cabbage leaf, lettuce and radish sprouts (Islam et al., 2014, 2016).

The present study aimed to investigate the inhibitory effect of these food additives including SFE C18, MFE C18, GY, MP, PT, PL and MSP on biofilms by $S$. Enteritidis, S. Typhimurium, Pseudomonas aeruginosa, P. fluorescens, Listeria monocytogenes, and Staphylococcus aureus on stainless-steel surfaces.

\section{MATERIALS AND METHODS}

\section{Bacterial strains and culture condition}

The 4 different bacterial species used in this study and their primary incubation conditions are listed in Table 1. Salmonella Enteritidis NBRC3313, S. Typhimurium NBRC12529, Pseudomonas aeruginosa NBRC13275 and Staphylococcus aureus NBRC13276 were obtained from NITE Biological Research Center (NBRC), Kazusakamatari, Kisarazu-shi, Chiba, Japan. Pseudomonas fluorescens FHC was isolated from lettuce and identified with RiboPrinter system in our laboratory. Listeria monocytogenes No. 185 was kindly offered by Public health center, Saku, Nagano, Japan. The stock cultures were maintained on Tryptic soy agar (TSA; Becton Dickinson, Franklin Lakes, NJ, USA) slants (TSA with $2 \% \mathrm{NaCl}$ for $S$. aureus) at $4^{\circ} \mathrm{C}$ and each strain was activated twice by transferring a loopful of bacteria to $5 \mathrm{~mL}$ of Luria-Bertani broth (LB; Becton Dickinson, Franklin Lakes, NJ, USA) or Tryptic soy broth (TSB; Becton Dickinson, Franklin Lakes, NJ, USA), and incubated overnight at $30^{\circ} \mathrm{C}$ or $37^{\circ} \mathrm{C}$ with shaking at $130 \mathrm{rpm}$ to obtain cells in stationary phase of growth. Then, $10 \mu \mathrm{L}$ of $1000-$ fold diluted culture broth was transferred and incubated at same condition. The cells were harvested by centrifugation $(6,000 \times g$ for $5 \mathrm{~min}$ at $4^{\circ} \mathrm{C}$ ) and the final pellets were resuspended with sterile water to an $\mathrm{OD}_{660}$ of 0.7 , corresponding to approximately $10^{9}-10^{10}$ colony-forming units (CFU) $/ \mathrm{mL}$.

\section{Preparation of stainless-steel washers and food additives solutions}

Stainless-steel washers (SUS304, inner diameter $2.3 \mathrm{~mm}$, outer diameter $6 \mathrm{~mm}$, thickness $0.4 \mathrm{~mm}$, unpolished) were used in this study. Prior to the experiments, washers were soaked in 10\% (v/v) alkaline detergent (DKS Co., Ltd., Kyoto, Japan) and ultrasonic cleaned by SONO Cleaner 100a (Kaijo Corporation, Matsumoto,
Nsgano, Japan) for $30 \mathrm{~min}$. Washers were rinsed with distilled water for 3 times, followed by immersion in 70\% alcohol and air dried in clean bench.

Protamine (PT) and Milk serum protein (MSP) ASAMA were provided by Asama Chemical Co., Ltd., Tokyo, Japan, Polylysine (PL) was purchased from Chisso Corporation, Tokyo, Japan, Sucrose fatty acid esters (SFE) was purchased from Mitsubishi-Kagaku Foods Corporation, Tokyo, Japan. Monascus pigment (MP) and Gardenia yellow (GY) were purchased from Wako pure Chemicals Co., Ltd, Tokyo, Japan. Monoglycerin fatty acid esters (MFE) were the products of Taiyo Kagaku Co., Ltd., Tokyo, Japan.

Food additive solutions were prepared as described by Miyamoto et al. (2011). For SFE C18 and MFE C18, two concentrations $(0.005 \%, 0.05 \%)$ were prepared by dissolving in pure water and autoclaved at $121^{\circ} \mathrm{C}$ for $20 \mathrm{~min}$, for GY \& MP (0.01\%, 0.1\%), PT \& PL (0.001\%, $0.01 \%, 0.1 \%)$ and $\operatorname{MSP}(0.0025 \%, 0.025 \%)$, they were dissolved in water and filter-sterilized with EB-DISK 25 (pore size $0.2 \mu \mathrm{m}$, Kanto Chemical Co., Ltd., Tokyo, Japan).

\section{Biofilm inhibition test on stainless-steel washers}

Adhesion or adhesion inhibition tests were done in 0.1\% Bacto-Soytone (BS, Becton-Dickinson, Franklin Lakes, NJ, USA) for $S$. Typhimurium, Brain Heart Infusion Broth (BHIB, Oxoid Ltd., Hampshire, UK) for $L$. monocytogenes, 1/5 BHIB for $P$. aeruginosa and $P$. fluorescens, and $1 / 5$ TSB supplemented with $2 \% \mathrm{NaCl}$ for $S$. aureus. Prepared stainless-steel washers were transferred to sterile round-bottom 96-well microtiter plates (SANPLATEC corp., Osaka, Japan) containing $100 \mu \mathrm{L}$ of media prepared at twice the concentration. Then, $50 \mu \mathrm{L}$ of prepared cell suspension and $50 \mu \mathrm{L}$ of food additive solutions were added to the well. For the control samples, $50 \mu \mathrm{L}$ food additive solutions were replaced with sterile water. Eight wells were used for every concentration of food additive solution. The plates were subsequently incubated under static conditions. The media and conditions for biofilm formation are shown in Table 1.

\section{Quantification of biofilm cells on stainless-steel washers}

After incubation for 24 or $48 \mathrm{~h}$, the stainless-steel washers were transferred to a new round-bottom plate and rinsed with $200 \mu \mathrm{L}$ phosphate-buffered saline (PBS,

Table 1. Bacterial strains, pre-culture and biofilm formation condition used in this study

\begin{tabular}{lll}
\hline Strains & Incubation conditions & Biofilm formation condition \\
\hline Salmonella Enteritidis NBRC3313 & $\mathrm{LB}^{\mathrm{a}}, 30^{\circ} \mathrm{C}$ & $0.1 \% \mathrm{BSb}^{\mathrm{c}}, 30^{\circ} \mathrm{C}, 24 \mathrm{~h}^{\circ}$ \\
Salmonella Typhimurium NBRC12529 & $\mathrm{LB}^{\mathrm{a}}, 30^{\circ} \mathrm{C}$ & $0.1 \% \mathrm{BSb}^{\mathrm{c}}, 30^{\circ} \mathrm{C}, 24 \mathrm{~h}^{\circ}$ \\
Pseudomonas aeruginosa NBRC13275 & $\mathrm{TSB}^{\mathrm{b}}, 30^{\circ} \mathrm{C}$ & $1 / 5 \mathrm{BHI}^{\mathrm{d}}, 30^{\circ} \mathrm{C}, 48 \mathrm{~h}$ \\
Pseudomonas fluorescens FHC & $\mathrm{TSB}^{\mathrm{b}}, 30^{\circ} \mathrm{C}$ & $1 / 5 \mathrm{BHI}^{\mathrm{d}}, 30^{\circ} \mathrm{C}, 48 \mathrm{~h}$ \\
Listeria monocytogenes No.185 & $\mathrm{TSB}^{\mathrm{b}}, 30^{\circ} \mathrm{C}$ & $\mathrm{BHI}^{\mathrm{d}}, 30^{\circ} \mathrm{C}, 24 \mathrm{~h}$ \\
Staphylococcus aureus NBRC13276 & $\mathrm{TSB}^{\mathrm{b}}$ with $2 \% \mathrm{NaCl}, 37^{\circ} \mathrm{C}$ & $1 / 5 \mathrm{TSB}^{\mathrm{b}}$ with $2 \% \mathrm{NaCl}, 37^{\circ} \mathrm{C}, 24 \mathrm{~h}$ \\
\hline
\end{tabular}

${ }^{a}$ Luria Broth (LB, Becton-Dickinson, Sparks, MD, USA), ${ }^{\text {b }}$ Tryptic soy broth (TSB, Becton-Dickinson, Sparks, MD, USA), ${ }^{c}$ Bacto-soytone (BSb, Becton-Dickinson, Sparks, MD, USA), ${ }^{d}$ Brain heart infusion (BHI, Oxoid Ltd., Hampshire, UK) 
$1.47 \mathrm{mM} \quad \mathrm{KH}_{2} \mathrm{PO}_{4}, \quad 8.10 \mathrm{mM} \quad \mathrm{Na}_{2} \mathrm{HPO}_{4}, 2.68 \mathrm{mM} \mathrm{KCl}$, $137 \mathrm{mM} \mathrm{NaCl}, \mathrm{pH} 7.4$ ) to remove planktonic cells and loosely attached bacterial cells. After drying on paper tissues (Nippon Paper Crecia Co., Ltd., Tokyo, Japan), the washers were transferred to another new round-bottom plate containing $100 \mu \mathrm{L}$ of $99 \%$ (v/v) ethanol and immersed for $5 \mathrm{~min}$. The washers were dried again and then stained with $100 \mu \mathrm{L}$ of $1 \%$ crystal violet (AMRESCO, Ohio, USA) for 5 min in a new round-bottom plate. The stained washers were gently rinsed twice using distilled water and dried in air. The total of 8 washers of each sample were collected and transferred to $2 \mathrm{~mL}$ test tube containing $300 \mu \mathrm{L}$ of $99 \%$ (v/v) ethanol, crystal violet was solubilized by ultrasonic agitation at room temperature for $30 \mathrm{~min}$. One-hundred and fifty of the mixture was transferred to a new flat-bottom plate, and its optical density was determined at $595 \mathrm{~nm}$ $\left(\mathrm{OD}_{595}\right.$; model 450, Bio-Rad Laboratories Japan, Tokyo, Japan).

\section{Enumeration of the planktonic cells}

Viable counts of bacteria were performed using conventional plating method as previously described by Miyamoto et al. (2009). After incubation with the food additives, $100 \mu \mathrm{L}$ of the cell suspension was pipetted from the wells, and serially diluted using sterile PBS. The serially diluted sample $(100 \mu \mathrm{L})$ was plated on TSA (TSA with $2 \% \mathrm{NaCl}$ for $S$. aureus) and incubated at $37^{\circ} \mathrm{C}\left(30^{\circ} \mathrm{C}\right.$ for $P$. aeruginosa and P. fluorescens) for $24 \mathrm{~h}$ before colony counting.

\section{Statistical analysis}

The relative adhesion of biofilm on the washers is expressed as the percentage of the non-treatment control formed biofilm. The viable cell counts are expressed as log values. The results of relative adhesion of biofilm on the washers and viable cell count are the average of two experimental replicates. Statistical analyses were performed using Microsoft Excel for Mac build 16.36 (Microsoft, Redmond, WA, USA).

\section{RESULTS}

\section{Effects of sucrose fatty acid ester}

The effects of SFE C18 on biofilm formation on stainless steel and viability of bacteria are shown in Figure 1. Biofilm formation of $S$. Enteritidis, $S$. Typhimurium and L. monocytogenes were strongly inhibited in the presence of $0.005 \%$ SFE C18 by nearly 70\%, 85\% and 40\%, respectively (Fig. 1A, B and E). In contrast, SFEC18 did not inhibit biofilm formation of $P$. aeruginosa, and $S$. aureus at all the concentrations tested (Fig. 1C and F). In the case of $P$. fluorescens, biofilm formation was reduced by about $50 \%$ at $0.05 \%$ (Fig. 1D). Viable bacterial counts of the planktonic cells did not change largely in the presence of SFE C18 even at $0.05 \%$.

\section{Effects of monoglycerin fatty ester}

The effects of MFE C18 on biofilm formation on stainless steel and viability of bacteria are shown in Figure 2. MFE C18 inhibited biofilm formation of $S$. Enteritidis and $P$. aeruginosa with the increase of the concentration. At $0.05 \%$ MFE C18, biofilm mass of $S$. Enteritidis and $P$. aeruginosa was reduced to about 50\% and 60\%, respectively (Fig. 2A and C). Similarly, MFE C18 at 0.005 and $0.05 \%$ caused about $50 \%$ reduction of

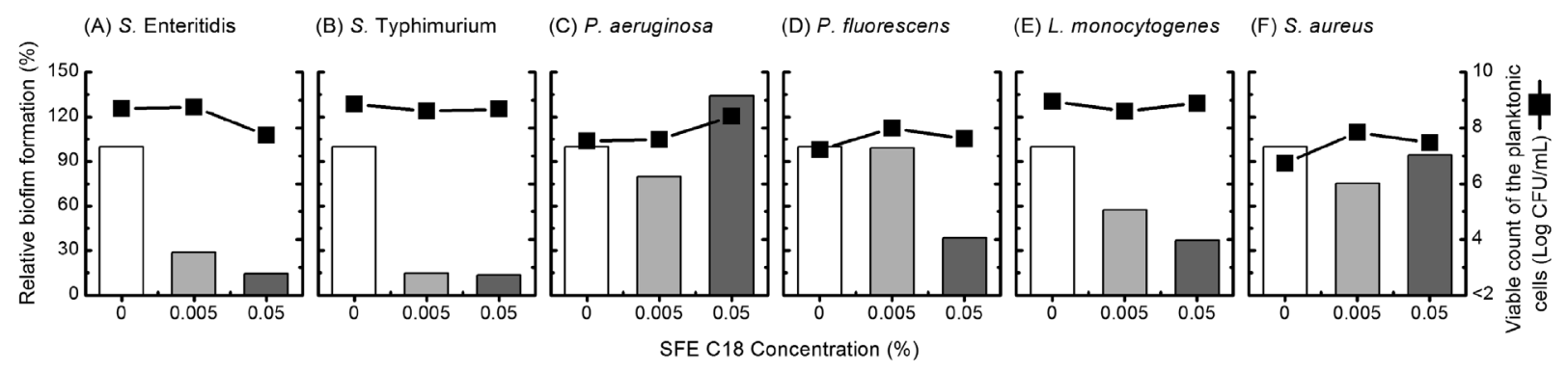

Fig. 1. Effect of SFE C18 on biofilm formation on stainless-steel. Bars and lines show the relative biofilm formation and viable counts of planktonic cells. (A) S. Enteritidis, (B) S. Typhimurium, (C) P. aeruginosa, (D) P. fluorescens, (E) L. monocytogenes, (F) S. aureus.

(A) S. Enteritidis

(B) S. Typhimurium

(C) $P$. aeruginosa

(D) P. fluorescens

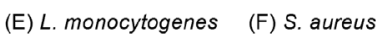
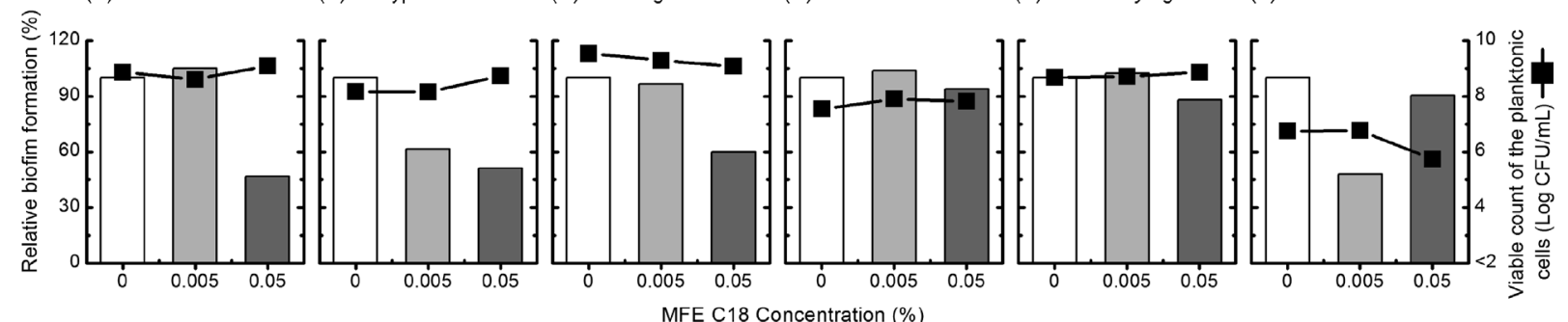

Fig. 2. Effect of MFE C18 on biofilm formation on stainless-steel. Bars and lines show the relative biofilm formation and viable counts of planktonic cells. (A) S. Enteritidis, (B) S. Typhimurium, (C) P. aeruginosa, (D) P. fluorescens, (E) L. monocytogenes, (F) S. aureus. 
biofilm formation of $S$. Typhimurium (Fig. 2B). In the case of $S$. aureus, MFE C18 inhibited biofilm formation at $0.005 \%$, but not at $0.05 \%$. In contrast, viable counts of $S$. aureus decreased by about 1-log in the presence of $0.05 \%$ MFE C18 (Fig. 2F). On the other hand, biofilm formation of $P$. fluorescens and L. monocytogenes did not change in the presence of the MFE (Fig. 2D and E).

\section{Effects of gardenia yellow pigment}

The effects of GY on biofilm formation on stainless steel and viability of bacteria are shown in Figure 3. GY was effective to inhibit biofilm formation of $S$. Enteritidis, S. Typhimurium and $S$. aureus (Fig. 3A, B and F). Specifically, GY was more effective on $S$. Typhimurium than the other two strains, showing $70 \%$ decrease in biofilm formation at $0.01 \%$ (Fig. 3B). Instead, GY did not affect biofilm formation of $P$. fluorescens and L. monocytogenes at all the concentrations tested (Fig. $\mathrm{D}$ and E). However, it promoted biofilm formation by $P$. aeruginosa (Fig. 3C). Viable bacterial counts were slightly decreased by about 1 log as the increasing concentration of GY in the case of $S$. Enteritidis, $S$. Typhimurium, $P$. aeruginosa, and $S$. aureus.

\section{Effects of monascus pigment}

The effects of MP on biofilm formation on stainless steel and viability of bacteria are shown in Figure 4. Generally, MP decreased biofilm formation of $S$. Enteritidis and $P$. aeruginosa on stainless-steel washers by about 70\% (Fig. 4A) and 50\% (Fig. 4C) at $0.1 \%$ without affecting viability. Contrary, MP promoted biofilm formation by $S$. aureus (Fig. 4F). It did not affect biofilm formation of L. monocytogenes and P. fluorescens (Fig. 4D and E).

\section{Effects of milk serum protein}

The effects of MSP on biofilm formation on stainless steel and viability of bacteria are shown in Figure 5.

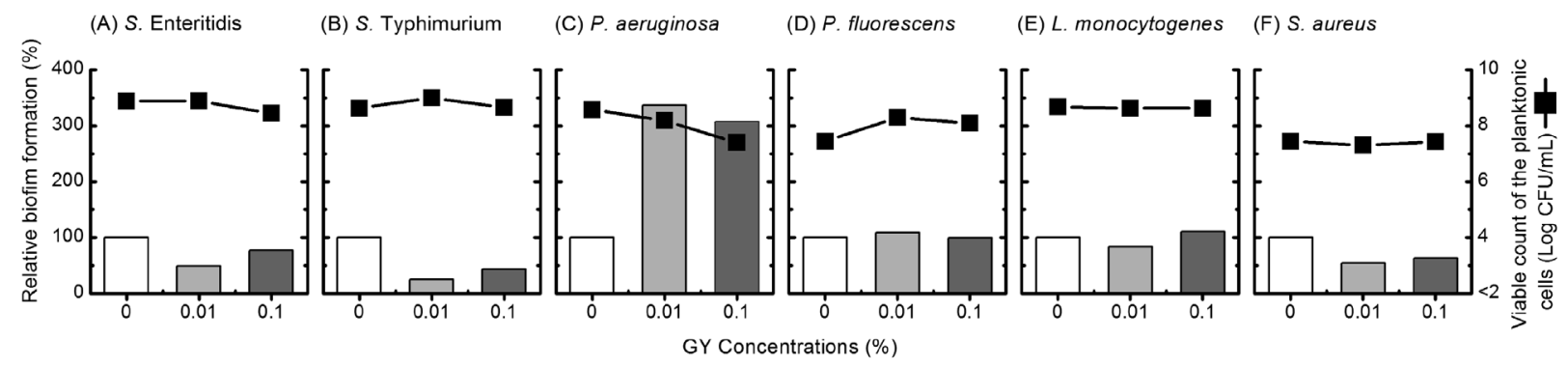

Fig. 3. Effect of GY on biofilm formation on stainless-steel. Bars and lines show the relative biofilm formation and viable counts of planktonic cells. (A) S. Enteritidis, (B) S. Typhimurium, (C) P. aeruginosa, (D) P. fluorescens, (E) L. monocytogenes, (F) S. aureus.

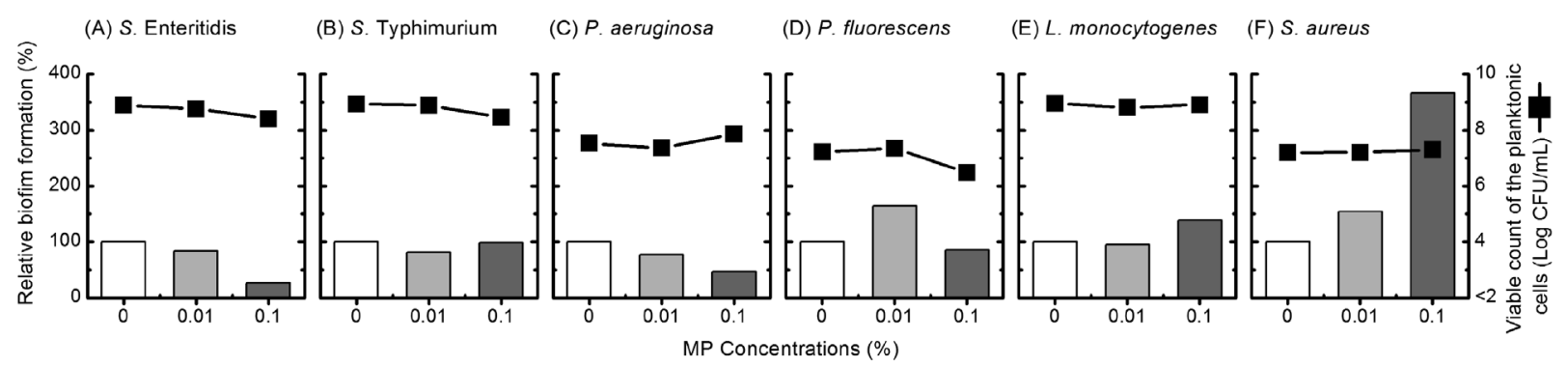

Fig. 4. Effect of MP on biofilm formation on stainless-steel. Bars and lines show the relative biofilm formation and viable counts of planktonic cells. (A) S. Enteritidis, (B) S. Typhimurium, (C) P. aeruginosa, (D) P. fluorescens, (E) L. monocytogenes, (F) S. aureus.

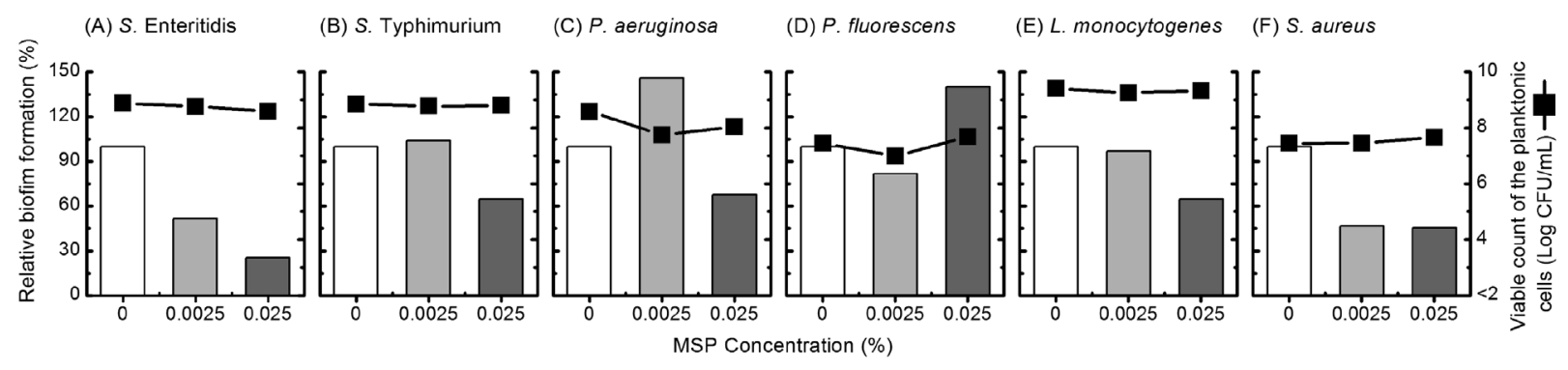

Fig. 5. Effect of MSP on biofilm formation on stainless-steel. Bars and lines show the relative biofilm formation and viable counts of planktonic cells. (A) S. Enteritidis, (B) S. Typhimurium, (C) P. aeruginosa, (D) P. fluorescens, (E) L. monocytogenes, (F) S. aureus. 


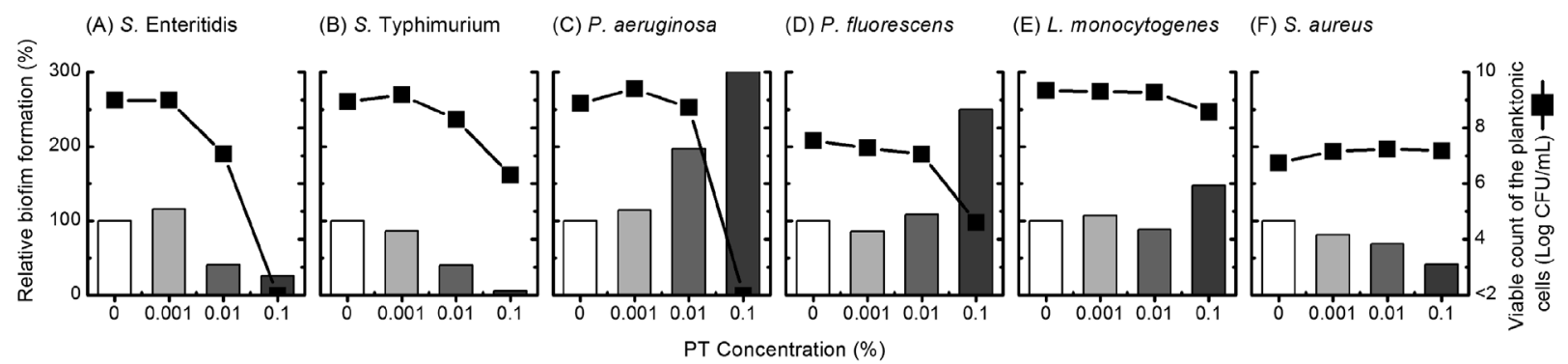

Fig. 6. Effect of PT on biofilm formation on stainless-steel. Bars and lines show the relative biofilm formation and viable counts of planktonic cells. (A) S. Enteritidis, (B) S. Typhimurium, (C) P. aeruginosa, (D) P. fluorescens, (E) L. monocytogenes, (F) S. aureus.

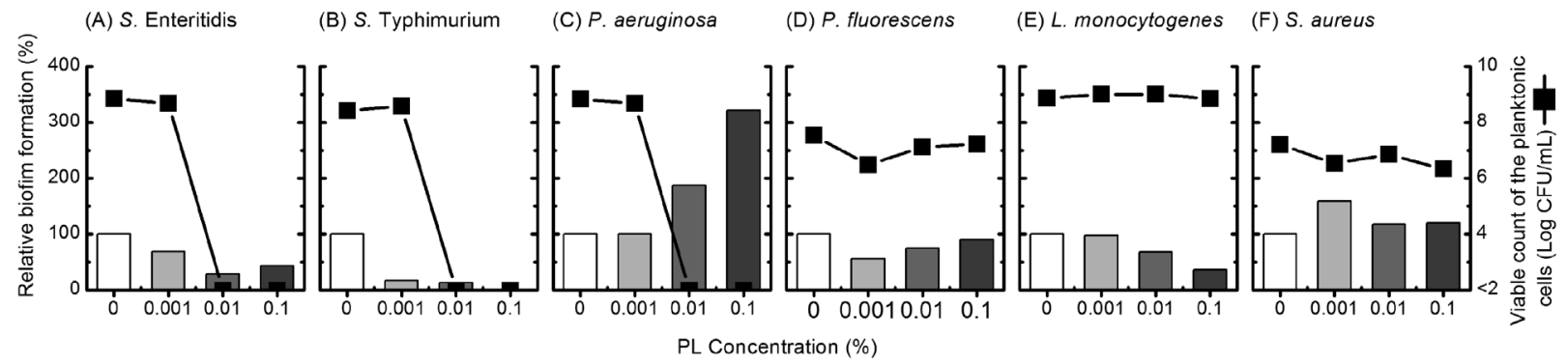

Fig. 7. Effect of PL on biofilm formation on stainless-steel. Bars and lines show the relative biofilm formation and viable counts of planktonic cells. (A) S. Enteritidis, (B) S. Typhimurium, (C) P. aeruginosa, (D) P. fluorescens, (E) L. monocytogenes, (F) S. aureus.

MSP showed inhibitory effect on biofilm formation of bacteria tested except for $P$. fluorescens (Fig. 5D). Biofilm mass of $S$. Enteritidis, $S$. Typhimurium, P. aeruginosa and L. monocytogenes were decreased with increasing concentration of MSP. Especially in $S$. Enteritidis, biofilm mass was decreased more than $70 \%$ in the presence of $0.025 \%$ MSP (Fig. 5A). For S. aureus, nearly $55 \%$ reduction of biofilm formation was observed at $0.0025 \%$ and $0.025 \%$ (Fig. 5 F). MSP did not decrease the viability of all the tested bacteria even at $0.025 \%$.

\section{Effects of protamine}

The effects of PT on biofilm formation on stainless steel and viability of bacteria are shown in Figure 6. PT greatly reduced the biofilm formation of $S$. Enteritidis, $S$. Typhimurium and $S$. aureus with increasing PT concentration. In the presence of $0.1 \%$ PT, biofilm mass was decreased by about $74,95,55 \%$ in $S$. Enteritidis, $S$. Typhimurium and $S$. aureus, respectively (Fig. 6A, B and $\mathrm{F}$ ). On the contrary, biofilm mass increased in $P$. aeruginosa, $P$. fluorescens and L. monocytogenes in the presence of $0.1 \%$ PT (Fig. 6C, D and E). Viable counts of planktonic cells largely decreased in $S$. Enteritidis, $P$. aeruginosa and $P$. fluorescens with increasing PT concentration, but not in L. monocytogenes and $S$. aureus.

\section{Effect of polylysine}

The effects of PL on biofilm formation on stainless steel and viability of bacteria are shown in Figure 7. PL inhibited biofilm formation on stainless steel by $S$. Enteritidis, S. Typhimurium, and L. monocytogenes with increasing PL concentration. The inhibitory effect was most strongly exerted on $S$. Typhimurium, being nearly $100 \%$ inhibition in the presence of $0.1 \%$ PL (Fig. 7B). Biofilm formation of $P$. fluorescens was slightly decreased by PL (Fig. 7D). However, PL was not effective on the biofilm formation of $P$. aeruginosa and $S$. aureus (Fig. 7C and F). Biofilm mas increased in $P$. aeruginosa in the presence of 0.01 and $0.1 \%$ PL in spite of the significant decrease in the viability of the planktonic cells (Fig. 7C). Significant decrease in the viability at $0.01 \%$ PL was also observed in $S$. Enteritidis, and $S$. Typhimurium, but not in P. fluorescens, L. monocytogenes, and $S$. aureus.

\section{DISCUSSION}

Biofilm formation of foodborne and spoilage bacteria is a particular concern for food manufacturing industries, as the occurrence of undesirable biofilms during food processing and storage may lead to foodborne illness, as well as food spoilage (Srey et al., 2013; Whitehead and Verran, 2015). However, it still remains challenging to find ideal strategies to control biofilm in food processing environment. In this study, effects of some selected food additives, which were proved to be effective on plastic surfaces for inhibiting biofilm formation of some bacteria (Miyamoto et al., 2011), were investigated on bacterial biofilm formation on stainless steel.

It was early demonstrated that fatty acid especially those with more than 12 carbons had the potent antimicrobial properties against Gram-positive bacteria 
(Kabara et al., 1972), and their derivatives by esterifying the fatty acid with polyhydric alcohols showed even stronger antimicrobial activity (Akoh, 1994). Based on these findings, more selective studies focused on antibacterial spectrum of their derivatives like sucrose fatty acid esters and monoglycerin fatty acid esters have been performed. For example, Conley and Kabara (1973) found that sucrose oleate and sucrose linoleate were effective against Gram-positive bacteria but not against Gram-negative bacteria. Furukawa et al. (2010) tested a wide range of food additives against biofilm formation by foodborne-pathogenic bacteria and observed that sugar fatty acid esters with 14-16 carbon chains possessed inhibitory effect on biofilm formation by $L$. monocytogenes at $0.01 \%(\mathrm{w} / \mathrm{w})$, but not on bacterial growth. Similarly, Schlievert and Peterson (2012) reported that glycerol monolaurate inhibited biofilm formation by $S$. aureus and Haemophilus influenzae in microtiter plates. In this study, SFE and MFE were both effective in reducing biofilm formation by $S$. Enteritidis and $S$. Typhimurium on stainless steel (Fig. 1 and 2). In addition, SFE also inhibited biofilm formation of $P$. fluorescens and L. monocytogenes (Fig. 1 ). These results on stainless steel were basically in accordance with the previous observations on microtiter plates mentioned above. The inhibitory activity of SFE and MFE is thought to be attributed to their amphipathic properties, which usually lead to destabilization of cell membrane, increased cell permeability or even cell lysis (Yoon et al., 2018).

Gardenia yellow is a natural colorant extensively used in food industry. Crocetin derivatives like crocin is one of the major components in GY, and their unique carotenoid-like polyene structure was reported to prevent $S$. Enteritidis from binding to collagen (Miyamoto et $a l ., 2003$ ) and adhering to microtiter plate (Miyamoto et al., 2009). Also, gentiobiose (a component of crocin) is presumed to bind to the surface of bacterial cells because of its hydrophilicity, which consequently inhibits the interactions between bacterial cell and the surfaces (Miyamoto et al., 2011). The biofilm formation of $S$. Enteritidis, $S$. Typhimurium and $S$. aureus on stainless steel surface were weakly inhibited by GY in this study. These results were similar to those reported on plastic surface (Miyamoto et al., 2011).

Monascus pigment has long been used as a natural food colorant in East Asia (Dufossé et al., 2005). It has been reported that MP has variety of biological activities including antimicrobial activities. Two orange constituents of MP, rubropunctatin and monascorubrin, were found to have strong antibiotic activities against Bacillus subtills and Candida pseudotropicalis (Martinkova, 1999). Natural pigments produced by Monascus ruber also showed antibacterial activity against $S$. aureus, Escherichia coli and S. Enteritidis (Vendruscolo et al., 2014). Biofilm formation of $S$. Enteritidis and $P$. aeruginosa was inhibited while that of $S$. aureus was promoted by $0.1 \%$ of MP, without affecting viability. The result on $S$. aureus is quite different from that by Miyamoto et al. (2011) reporting inhibition of the adhesion $S$. aureus on microplate by MP. It seems important to know the difference in the mechanism for biofilm formation of $S$. aureus on polystyrene and stainless-steel surfaces for developing an effective method for inhibiting biofilm formation by $S$. aureus.

Milk serum refers to the milk minus milk fat globules and casein micelles, and the soluble protein separated and concentrated from milk serum is called milk serum protein (Walstra, 1999). Because it is produced without exposure to enzymes or chemicals in the cheese-making process, it is regarded as "native" whey proteins (Evans et al., 2009). The whey protein includes bioactive compounds like $\beta$-lactoglobulin and $\alpha$-lactalbumin, as well as some antibacterial peptides, which have been reported to control of microbial infections (Atanasova and Ivanova, 2010). In the present study, MSP reduced biofilm formation of $S$. Enteritidis and $S$. aureus but not those of Pseudomonas. To know the detailed inhibitory mechanism for biofilm formation, effects of each of the components of MSP will be further investigated.

Protamine is a broad-spectrum antimicrobial peptide existed in the sperm cells of vertebrates like fish (Truelstrup Hansen et al., 2001). Protamine is usually positively charged due to the high content of arginine. It attaches to negatively charged cell surface through electrostatic interactions, causing leakage of $\mathrm{K}^{+}$, ATP and intracellular substances and exerting antibacterial action (Islam et al., 1987; Johansen et al., 1997; Stumpe and Bakker, 1997). Protamine has been studied to control pathogens including E. coli (Hansen and Gill, 2000), L. monocytogenes (Uyttendaele and Debevere, 1994), P. aeruginosa (Boussard et al., 1994) and S. Typhimurium (Aspedon and Groisman, 1996). Likewise, polylysine is also a natural antimicrobial peptide with positive charge, and has antibacterial activity against Gram-positive and Gram-negative bacteria, yeast and fungi (Hiraki, 2000). The antibacterial mechanism of polylysine is thought to be similar with protamine (Ye et al., 2013; Hyldgaard et al., 2014; Lin et al., 2018; Li et al., 2019), but its antibacterial activity is stronger than PT (Conte et al., 2007). In our previous study, PT and PL significantly inhibited the biofilm formation of the same bacteria tested in this study on plastic surface (Miyamoto et al., 2011). In this study, the biofilm formation on the surface of stainless steel was largely decreased in $S$. Enteritidis, $S$. Typhimurium and $S$. aureus, but increased in $P$. aeruginosa, P. luorescens and L. monocytogenes by $0.1 \%$ PT (Fig. 6). Meanwhile, the viable counts of planktonic cells of Gram-negative bacteria were significantly decreased by PT at the same concentration. Similar to PT, $0.01 \%$ PL inhibited biofilm formation of $S$. Enteritidis and $S$. Typhimurium but promoted that of $P$. aeruginosa. Almost all the planktonic cells of these 3 species were killed by PL at the same concentration (Fig. 7). These results on biofilm formation of Pseudomonas on stainless-steel surface were quite different from the results on plastic surface, suggesting that cellular components released from Pseudomonas cells killed by PT and PL attached and accumulated on the surface of stainless steel. 
This study suggests that different pathogens have diverse response during their exposure to the food additives on the stainless-steel surface. Application of some of selective food additives is promising to control bacterial biofilm formation of pathogenic and spoilage bacteria in food processing environments though the selection of the additive suitable to the target bacteria is important.

\section{AUTHOR CONTRIBUTIONS}

C. SHEN performed the analysis and wrote the paper. C. MACHIDA performed the experiments and collected the data. Y. MASUDA and K. HONJOH commented on the manuscript. T. MIYAMOTO designed the study, supervised the work, and wrote the paper. All authors assisted in editing the manuscript and approved the final version.

\section{REFERENCES}

Akoh, C. C. 1994. Carbohydrate polyesters as fat substitutes. 1st ed. CRC Press, Boca Raton (Florida) pp 149-168

Aspedon, A and E. A. Groisman 1996 The antibacterial action of protamine: evidence for disruption of cytoplasmic membrane energization in Salmonella typhimurium. Microbiology., 142: 3389-3397. https://doi.org/10.1099/13500872-142-12-3389

Atanasova, J and I. Ivanova 2010 Antibacterial peptides from goat and sheep milk proteins. Biotechnol. Biotechnol. Equip., 24: 1799-1803. https://doi.org/10.2478/V10133-010-0049-8

Beuchat, L. R. 2002 Ecological factors influencing survival and growth of human pathogens on raw fruits and vegetables. Microbes Infect., 4: 413-423. https://doi.org/10.1016/S12864579(02)01555-1

Boussard, P., M. Devleeschouwer and J. Dony 1994 Influence of protamine on the in vitro sensitivity of Pseudomonas aeruginosa to antibiotics. Pharm. Acta Helv., 68: 161-167. https:// doi.org/10.1016/0031-6865(94)90038-8

Conley, A. J. and J. J. Kabara 1973. Antimicrobial action of esters of polyhydric alcohols. Antimicrob. Agents Chemother., 4: 501-506. https://doi.org/10.1128/AAC.4.5.501

Conte, M., F. Aliberti, L. Fucci and M. Piscopo 2007. Antimicrobial activity of various cationic molecules on foodborne pathogens. World J. Microbiol. Biotechnol., 23: 1679-1683. https://doi. org/10.1007/s11274-007-9415-6

Diaz, M., V. Ladero, B. del Rio, B. Redruello, M. Fernández, M.C. Martin and M.A. Alvarez 2016. Biofilm-forming capacity in biogenic amine-producing bacteria isolated from dairy products. Front. Microbiol., 7: 591. https://doi.org/10.3389/fmicb.2016. 00591

Dufossé, L., P. Galaup, A. Yaron, S. M. Arad, P. Blanc, K. N. Chidambara Murthy and G. A. Ravishankar 2005. Microorganisms and microalgae as sources of pigments for food use: a scientific oddity or an industrial reality? Trends Food Sci. Technol., 16(9): 389-406. https://doi.org/10.1016/j. tifs.2005.02.006

Evans, J., J. Zulewska, M. Newbold, M. A. Drake and D. M. Barbano 2009. Comparison of composition, sensory, and volatile components of thirty-four percent whey protein and milk serum protein concentrates. J. Dairy Sci., 92(10): 4773-4791. https:// doi.org/10.3168/jds.2009-2194

Furukawa, S., Y. Akiyoshi, G. A. O'Toole, H. Ogihara and Y. Morinaga 2010. Sugar fatty acid esters inhibit biofilm formation by food-borne pathogenic bacteria. Int. J. Food Microbiol., 138: 176-180. https://doi.org/10.1016/j.ijfoodmicro.2009.12.026

Hansen, L. T. and T. A. Gill 2000. Solubility and antimicrobial efficacy of protamine on Listeria monocytogenes and Escherichia coli as influenced by pH. J. Appl. Microbiol., 88:
1049-1055. https://doi.org/10.1046/j.1365-2672.2000.01074.x

Hiraki, J 2000. $\varepsilon$-Polylysine, its development and utilization. Fine Chem., 29: 18-25

Hyldgaard, M., T. Mygind, B. S. Vad, M. Stenvang, D. E. Otzen and R. L. Meyer 2014. The antimicrobial mechanism of action of Epsilon-Poly-1-Lysine. Appl. Environ. Microbiol., 80: 77587770. https://doi.org/10.1128/AEM.02204-14

Islam, M. T., A. Oishi, C. Machida, A. Ogura, S. Kin, K. Honjoh and T. Miyamoto 2014. Combined effects of selected food additives on adhesion of various foodborne pathogens onto microtiter plate and cabbage leaves. Food Control., 46: 233-241. https://doi.org/10.1016/j.foodcont.2014.05.034

Islam, M. T., A. Ogura, C. Machida, N. Morinaga, K. Honjoh and T. Miyamoto 2016. Effects of $\varepsilon$-polylysine and milk serum protein on the attachment and decontamination of Salmonella Enteritidis on lettuce and radish Sprouts. Food Sci. Technol. Res., 22: 703-711. https://doi.org/10.3136/fstr.22.703

Islam, N. M., H. Oda and T. Motohiro 1987. Changes in the cell morphology and the release of soluble constituents from the washed cells of Bacillus subtilis by the action of protamine. Nippon Suisan Gakkaishi., 53: 297-303. https://doi.org/ 10.2331/suisan.53.297

Johansen, C., A. Verheul, L. Gram, T. Gill and T. Abee 1997. Protamine-induced permeabilization of cell envelopes of grampositive and gram-negative bacteria. Appl. Environ. Microbiol., 63: $1155-1159$

Kabara, J. J., D. M. Swieczkowski, A. J. Conley and J. P. Truant 1972. Fatty acids and derivatives as antimicrobial agents. Antimicrob. Agents Chemother., 2: 23-28. https://doi.org/ 10.1128/AAC.2.1.23

Li, H., C. He, G. Li, Z. Zhang, B. Li and S. Tian 2019. The modes of action of epsilon-polylysine ( $\varepsilon-\mathrm{PL})$ against Botrytis cinerea in jujube fruit. Postharvest Biol. Technol., 147: 1-9. https:// doi.org/10.1016/j.postharvbio.2018.08.009

Lin, L., Y. Gu, C. Li, S. Vittayapadung and H. Cui 2018. Antibacterial mechanism of $\varepsilon$-Poly-lysine against Listeria monocytogenes and its application on cheese. Food Control., 91: 76-84. https://doi.org/10.1016/j.foodcont.2018.03.025

Martinkova, L. 1999. Biological activities of oligoketide pigments of Monascus purpureus. Food Addit. Contam., 16: 15-24. https://doi.org/10.1080/026520399284280

Meireles, A., E. Giaouris and M. Simões 2016. Alternative disinfection methods to chlorine for use in the fresh-cut industry. Food Res. Int., 82: 71-85. https://doi.org/10.1016/j.foodres. 2016.01 .021

Miyamoto, T., Y. Shimizu, H. Kobayashi, K. Honjoh and M. Iio 2003. Studies of collagen binding with immobilized Salmonella enteritidis and inhibition with synthetic and naturally occurring food additives by a surface plasmon resonance biosensor. Sens. Mater., 15: 453-466

Miyamoto, T., J. Kawaguchi, S. Shimotsu, J. Kawagishi and K. Honjoh 2009. Inhibitors of adhesion ability of Salmonella Enteritidis. J. Jpn. Soc. Food Sci. Technol., 56: 200-208. https://doi.org/10.3136/nskkk.56.200

Miyamoto, T., J. Kawagishi, A. Oishi, S. Shimotsu, T. Mishima, H. Kobayashi and K. Honjoh 2011. Inhibition of adhesion of several bacteria onto microtiter plate by selected food additives. Jpn. J. Food Microbiol., 28: 157-166. https://doi.org/10.5803/ jsfm.28.157

Schlievert, P. M and M. L. Peterson 2012. Glycerol monolaurate antibacterial activity in broth and biofilm cultures. PLOS ONE 7(7): e40350. https://doi.org/10.1371/journal.pone.0040350

Srey, S., I. K. Jahid and S. D, Ha 2013. Biofilm formation in food industries: A food safety concern. Food Control 31: 572-585. https://doi.org/10.1016/j.foodcont.2012.12.001

Stumpe, S. and E. P. Bakker 1997. Requirement of a large $\mathrm{K}^{+}$uptake capacity and of extracytoplasmic protease activity for protamine resistance of Escherichia coli. Arch. Microbiol., 167: 126-136. https://doi.org/10.1007/s002030050425

Hansen, L. T., J. W. Austin and T. A. Gill 2001. Antibacterial effect of protamine in combination with EDTA and refrigeration. Int. J. Food Microbiol., 66: 149-161. https://doi.org/10.1016/ 
S0168-1605(01)00428-7

Uyttendaele, M. and J. Debevere 1994. Evaluation of the antimicrobial activity of protamine. Food Microbiol., 11: 417-427. https://doi.org/10.1006/fmic.1994.1047

Vendruscolo, F., I. Tosin, A. J. Giachini, W. Schmidell and J. L. Ninow 2014. Antimicrobial activity of monascus pigments produced in submerged fermentation. J. Food Process. Preserv., 38: 1860-1865. https://doi.org/10.1111/jfpp.12157

Walstra, P. 1999 Dairy Technology: principles of milk properties and processes. CRC Press, Boca Raton (Florida), pp. 471483

Whitehead, K. A. and J. Verran 2015. Formation, architecture and functionality of microbial biofilms in the food industry. Curr. Opin. Food Sci., 2: 84-91. https://doi.org/10.1016/j.cofs.
2015.02 .003

World Health Organization, 2015. WHO estimates of the global burden of foodborne diseases. Retrieved May, 2020 from https:// www.who.int/foodsafety/publications/foodborne_disease/fergreport/en/

Ye, R., H. Xu, C. Wan, S. Peng, L. Wang, H. Xu, Z.P. Aguilar, Y. Xiong, Z. Zeng and H. Wei 2013. Antibacterial activity and mechanism of action of $\varepsilon$-poly-l-lysine. Biochem. Biophys. Res. Commun., 439: 148-153. https://doi.org/10.1016/j.bbrc. 2013.08.001

Yoon, B. K., J. A. Jackman, E. R. Valle-González and N. J. Cho 2018. Antibacterial free fatty acids and monoglycerides: biological activities, experimental testing, and therapeutic applications. Int. J. Mol. Sci., 19: 1114. https://doi.org/10.3390/ijms19041114 